\title{
EFFECT OF FOLIAR SPRAYING WITH GROWTH PROMOTERS AND NITROGEN FERTILIZER LEVELS ON GROWTH AND YIELD OF MAIZE
}

\author{
Badawi, M. A.* ; A. N. E. Attia* ; A. A. Leilah ${ }^{*}$ and \\ Rasha S. A. EL-Moursy ${ }^{\star \star}$ \\ *Agronomy Department, Faculty of Agriculture, Mansoura University. \\ *Agronomy Department, Faculty of Agriculture, Damietta University.
}

\begin{abstract}
Two field experiments were performed at the Experimental Station, Faculty of Agriculture, Mansoura University, during the two successive summer seasons of 2010 and 2011. The main objective of this study was maximizing maize hybrid S.C. 128 productivity through determining optimum nitrogen fertilizer level and foliar spraying with growth promoters treatment. A strip plot design with four replicates was used. The obvious results of this investigation can be summarized as follows:

Application nitrogen fertilization at the level of $130 \mathrm{~kg} \mathrm{~N} / \mathrm{fed}$ significantly exceeded other studied levels (90 and $110 \mathrm{~kg} \mathrm{~N} / \mathrm{fed}$ ) in growth parameters, yield attributes, grain yield and protein percentage in grains in both seasons.

Foliar spraying maize plants with Aminototal after 25 and 35 DFS resulted in the highest values of studied growth characters and protein $\%$ in grains in both seasons. However, foliar spraying with Melagrow after $25+35$ days from sowing gave the highest values of number of ears/plant, ear length and diameter, ear weight, number of rows/ear, number of grains/row, ear grains weight, 100-grain weight and grain yield/fed in both seasons. Foliar spraying with Aminototal after $25+35$ DFS came in the second rank after foliar spraying with Melagrow without significant differences between them in both seasons.

Generally, it can be concluded that according to the obtained results from this study, mineral fertilizing maize plants hybrid S.C. 128 with $130 \mathrm{~kg} \mathrm{~N} / \mathrm{fed}$ and foliar spraying with Melagrow or Aminototal twice after 25 and 35 days from sowing in order to maximizing its growth and productivity under the environmental conditions of ElMansoura district, Dakahlia Governorate.
\end{abstract}

\section{INTRODUCTION}

Maize (Zea mays L.) is a cereal crop that is grown widely throughout the world. After the wheat and rice, maize is the most important cereal grain in the world, providing nutrients for humans and animals. In Egypt, maize is considered as one of the main cereal crops, comes the third after wheat and rice. Maize is very essential either for the human food or animal feeding and a common ingredient for industrial products. It plays a vital source of daily human food because their flour mixed with wheat flour by $20 \%$ for bread making. Also, maize is used as a feed for livestock whether fresh, silage or grains. Therefore, a great attention should be paid to raise maize productivity by maximizing yield per unit area in order to reduce the gap between its production and consumption. Where, maize is well known for its high demand for nutrients and other production inputs. Thereby, nitrogen fertilizer levels 


\section{Badawi, M. A. et al.}

and foliar spraying with growth promoters are among factors that enhance maize productivity.

Maize as a $\mathrm{C}_{4}$ plant, uptakes a large amount of nutrients from soil during its growth period. The level of nitrogen fertilizer has more influence on the growth and yield of maize than any other plant nutrient because it is the nutrient most often deficient in the Egyptian soils. Consequently, increasing application of nitrogen fertilizer levels led to significant increases in growth, yield and its attributes and quality characters of maize crop. (Abd-Alla, 2005 ; Ma et al., 2005 ; Abd El-Lattief and Fakkar, 2006 ; Soliman, Salwa, 2006 ; Seadh and El-Zehery, 2007 ; Abdel-Hafez et al., 2008 ; Sharifi and Taghizadeh, 2009 ; Arif et al., 2010 ; Soliman and Gharib, 2011 ; Attia et al., 2012 and El-Naggar, Nehal et al., 2012). In spite of mineral fertilizers have a good effect on plant productivity; Wopereis et al. (2006) concluded that excess application of nitrogen fertilizer could be accumulated in plant tissues in freely manner; this also affects human health and crop quality. Thus, judicious use of mineral nitrogen fertilizer should be promoted on improvement maize productivity.

During the last decade, there is a great demand for agro-chemical residue free fresh agricultural products. There is a worldwide trend to explore new natural products that act as growth promoters for plants, giving priority to that enhance the plant productivity and avoid negative and side effects on human health as a result of the excessive application of synthetic agrochemicals. In this regard; Sawyer and Barker (2000) found that foliar application of mono-potassium phosphate (MKP), urea, or a combination of the two fertilizers at several growth stages would not be recommended for corn production. Ling and Silberbush (2002) concluded that foliar fertilization may partially compensate for insufficient uptake by the roots, but requires sufficient leaf area to become effective. Darwish (2003) reported that spraying maize plants with $\mathrm{Zn}$ and $\mathrm{Fe}$ increased ear length, 100 grain weight, grain yield/fed and protein percentage in grains. Mohamed (2006) indicated that Dlefan fertilizers gave considerable increases in plant height, ear leaf area, ear diameter, length and weight, number of grains/row, the final grain yield either per plant or per feddan and shelling \% when compared with the check treatment. Naderi et al. (2009) indicated that effect of foliar application with "Biomin" on 1000 grain weight and grain yield at different growth stages was significant at $1 \%$ level. Potarzycki and Grzebisz (2009) found that maize crop responded significantly to zinc foliar application in two seasons of study. The optimal rate of zinc foliar spray for achieving significant grain yield response was in the range from 1.0 to $1.5 \mathrm{~kg} \mathrm{Zn/ha}$. Radulov et al. (2010) indicated that grain yield increase have resulted in lower protein concentration, except when the yield increase resulted from nitrogen fertilizer application. Fertilization with foliar fertilizers containing different N,P,K quantities not only increased the protein content of corn, but it also affected the relative proportion of the various amino acids in the protein of corn. Ali et al. (2011) found that foliar application with natural source of cytokinins i.e., leaf extract of Moringa olifera significantly improved the leaf area, plant height, root fresh and dry weights of maize. El-Azab (2012) studied the effect of foliar fertilization treatments (without, foliar spraying with water, Crystal 
Nasr and Melagrow after 25 and 45 days from sowing) on yield and its attributes of maize. He revealed that foliar spraying maize plants with Melagrow significantly increased yield and its attributes and also produced the highest values of these characters. On the other hand, plants growing without foliar spraying gave the lowest ones. Kasraie et al. (2012) showed that the times spraying of Amino Acid had a significant effect on the characteristics of number of rows/ear, number of grains/row, 1000-grain weight, grain yield and protein percentage. Maximum grain yield/ha, number of ears/plant, number of rows/ear, number of grains/row, 1000-grain weigh were obtained from Amino Acid foliar before water deficit stress. Seadh et al. (2012) reported that spraying safflower plants with Melagrow as a natural growth promoter two times after 30 and 70 days from sowing produced the highest values of seed yield and its attributes. On the other wise, the control treatment (without foliar fertilization) gave the lowest values of these characters.

Therefore, this study was established to determine the optimum level of mineral nitrogen fertilizer and foliar spraying treatment in order to maximize maize hybrid Single Cross 128 (S.C. 128) productivity under the environmental conditions of Mansoura district, Dakahlia Governorate.

\section{MATERIALS AND METHODS}

A field experiment was carried out at the Experimental Station, Faculty of Agriculture, Mansoura University, during the two successive summer seasons of 2010 and 2011. The main objective of this study was maximizing maize hybrid S.C. 128 productivity through determining optimum nitrogen fertilizer level and foliar spraying with growth promoters treatment.

The experiment was carried out in a strip plot design with four replications. The vertical plots were assigned to three nitrogen fertilizer levels i.e. $\mathrm{N}_{1}-90 \mathrm{~kg} \mathrm{~N} / \mathrm{fed}, \mathrm{N}_{2}-110 \mathrm{~kg} \mathrm{~N} / \mathrm{fed}$ and $\mathrm{N}_{3}-130 \mathrm{~kg} \mathrm{~N} / \mathrm{fed}$. Nitrogen fertilizer in the form of ammonium nitrate $(33.5 \% \mathrm{~N})$ was added at the formerly mentioned levels in two equal portions, one half after thinning (before the first irrigation) and the other half before the second irrigation.

The horizontal plots were occupied with the following ten foliar spraying with growth promoter treatments; $\mathrm{F}_{1}$ - Without (control treatment), $\mathrm{F}_{2-}$ Spraying with water after 25 days from sowing, $\mathrm{F}_{3}$ - Spraying with water after 35 days from sowing, $F_{4}$ - Spraying with water after 25 and 35 days from sowing, $\mathrm{F}_{5}$ - Spraying with Melagrow after 25 days from sowing at the rate of $50 \mathrm{ppm}$ (10 g Melagrow/200 liter water/fed), $\mathrm{F}_{6}$ - Spraying with Melagrow after 35 days from sowing at the rate of $50 \mathrm{ppm}(10 \mathrm{~g}$ Melagrow/200 liter water/fed), $\mathrm{F}_{7}-$ Spraying with Melagrow after 25 and 35 days from sowing at the rate of $25 \mathrm{ppm}\left(5 \mathrm{~g}\right.$ Melagrow/200 liter water/fed) for each, $\mathrm{F}_{8-}$ Spraying with Aminototal after 25 days from sowing at the rate of $1000 \mathrm{ppm}(200 \mathrm{~g}$ Aminototal/200 liter water/fed), F9- Spraying with Aminototal after 35 days from sowing at the rate of $1000 \mathrm{ppm}(200 \mathrm{~g} \mathrm{Aminototal} / 200$ liter water/fed) and $\mathrm{F}_{10}$ - Spraying with Aminototal after 25 and 35 days from sowing at the rate of $500 \mathrm{ppm}$ (100 g Aminototal/200 liter water/fed) for each. 


\section{Badawi, M. A. et al.}

Melagrow is natural growth promoter extracted from pollen of cabbage flowers. It has great effectiveness of many field crops. Melagrow has combined effects of oxen, cytokinens, gibberellins, ethylene and hydrogen cyanamid. The chemical composition of Melagrow is $20 \%$ phosphorus, $10 \%$ potassium, $3 \%$ boron and $0.2 \%$ brassinolide. Natural brassinolides $(0.2 \%)$ is natural plant growth promoter for all crops, which promotes growth, increases yield and improves quality. Aminototal is consisting of 17 kinds of free amino acids in L-amino acids form as presented in Table 1. It improves the plant tolerance to stresses or adverse conditions i.e. high temperature, drought and salinity. Some amino acids play an important role in synthesis of some hormones such as auxins, increasing chlorophyll concentration, consequently increasing photosynthesis and act as chelating factor which help in transport and absorption of micronutrients.

Table 1: Chemical composition of Aminototal foliar fertilizer.

\begin{tabular}{|l|c|l|c|}
\hline Aminototal content & Concentrate (\%) & Aminototal content & Concentrate (\%) \\
\hline Threonine & $3.05-3.56$ & Valine & $2.80-3.10$ \\
\hline Aspartic & $3.20-3.45$ & Methionene & $0.23-0.31$ \\
\hline Serein & $3.76-4.49$ & Leucine & $1.98-2.80$ \\
\hline Glutamic & $7.24-9.12$ & lso Leucine & $1.26-1.70$ \\
\hline Proline & $2.23-3.50$ & Phenylalamine & $1.03-1.78$ \\
\hline Glysine & $1.87-2.43$ & Histidine & $0.42-0.90$ \\
\hline Alanine & $2.16-2.20$ & Arginine & $5.20-6.30$ \\
\hline Cystine & $1.87-2.45$ & Tyrosine & $0.48-1.02$ \\
\hline Lysine & $1.39-2.30$ & & \\
\hline
\end{tabular}

Each experimental basic unit included five ridges, each of $70 \mathrm{~cm}$ width and $3.0 \mathrm{~m}$ length, resulted an area of $10.5 \mathrm{~m}^{2}$ (1/400 fed). The preceding winter crop was Egyptian clover (Trifolium alexandrinum L.) in both seasons.

Soil samples were taken at random from the experimental field area at a depth of $0-30 \mathrm{~cm}$ from soil surface before soil preparation during the growing seasons to measure the physical and chemical soil properties as shown in Table 2.

The experimental field well prepared through two ploughing, leveling, and compacting, ridging and then divided into the experimental units (10.5 $\left.\mathrm{m}^{2}\right)$. Calcium superphosphate $\left(\begin{array}{lll}15.5 & \% & \mathrm{P}_{2} \mathrm{O}_{5}\end{array}\right)$ was applied during soil preparation at the rate of $150 \mathrm{~kg} / \mathrm{fed}$. Potassium sulphate $\left(48 \% \mathrm{~K}_{2} \mathrm{O}\right)$ at the rate of $50 \mathrm{~kg} / \mathrm{fed}$ was applied at the first dose of nitrogen fertilizer.

Maize grains were hand sown in hills $25 \mathrm{~cm}$ apart at the rate of $2-3$ grains/hill using dry sowing method (Afeer) on one side of the ridge on $8^{\text {th }}$ and $11^{\text {th }}$ May in 2010 and 2011 seasons, respectively. The plants were thinned to one plant per hill before the first irrigation. The first irrigation was applied after 18 days from sowing and the following irrigations were applied at 12 days intervals during the growing seasons. The other agricultural practices were kept the same as normally practiced in maize fields according to the recommendations of Ministry of Agriculture and Land Reclamation, except for the factors under study. 
Table 2: Mechanical and chemical soil characteristics at the experimental sites during the two growing seasons of 2010 and 2011.

\begin{tabular}{|l|c|c|}
\hline \multicolumn{1}{|c|}{ Soil analysis } & 2010 season & 2011 season \\
\hline Sand \% & 28.79 & 28.26 \\
\hline Silt \% & 29.55 & 30.94 \\
\hline Clay \% & 41.66 & 40.8 \\
\hline Texture & Clayey & Clayey \\
\hline Organic matter \% & 1.98 & 1.93 \\
\hline Available N $(\mathrm{ppm})$ & 25.42 & 24.40 \\
\hline Available P $(\mathrm{ppm})$ & 14.60 & 3.74 \\
\hline Exchangeable K $(\mathrm{ppm})$ & 316.20 & 7.77 \\
\hline pH & 7.62 & 2.66 \\
\hline EC m. mohs $/ \mathrm{cm}$ at $25^{\circ} \mathrm{C}$ & 2.31 & 08.40 \\
\hline
\end{tabular}

\section{Studied Characters:}

A- Growth characters:

1- Number of days from sowing to $50 \%$ tasseling: This character was determined as the number of days from planting to $50 \%$ tasseling of each plot.

After 100 days from planting, random samples of ten guarded plants were taken from each plot to determine the following growth characters:

2- Plant height $(\mathrm{cm})$. 3- Ear height $(\mathrm{cm})$. 4 - Stem diameter $(\mathrm{cm})$.

5- Ear leaf area $\left(\mathrm{cm}^{2}\right)$ was calculated as follows:

Ear leaf area $=$ leaf length $X$ maximum width of ear leaf $X 0.75$, according to Gardner et al. (1985).

\section{B- Yield and its attributes:}

At harvest (after 120 days from planting) random samples of five guarded plants and ears were taken from each plot to determine the following yield and its components:

6- Number of ears/plant.

8- Ear diameter $(\mathrm{cm})$.

7- Ear length $(\mathrm{cm})$.

10- Number of rows/ear.

9- Ear weight (g).

12- Ear grains weight $(\mathrm{g})$.

11- Number of grains/row.

13- Shelling percentage.

14- 100-grain weight (g).

15- Grain yield (ardab/fed): It was determined by the weight of grains per kilograms adjusted to $15.5 \%$ moisture content of each plot, then converted to ardab per feddan ( $\operatorname{ardab}=140 \mathrm{~kg}$ ).

16- Crude protein percentage: It was estimated by the improved Kjeldahl method according to A.O.A.C. method (1990), modified by distilling the ammonia into saturated boric solution and titration in standard acid. Crude protein percentage was calculated by multiplying the total nitrogen values in maize flour by 6.25 .

All obtained data were statistically analyzed according to the technique of analysis of variance (ANOVA) for the strip plot design as published by Gomez and Gomez (1984), using MSTAT statistical package (MSTAT-C with MGRAPH version 2.10, Crop and Soil Sciences Department, Michigan State University, USA). Least Significant of Difference (LSD) 
Badawi, M. A. et al.

method was used to test the differences between treatment means at $5 \%$ level of probability as described by Snedcor and Cochran (1980).

\section{RESULTS AND DISCUSSION}

\section{1- Effect of nitrogen fertilizer levels:}

The obtained data in Table 3 revealed that the effect of nitrogen fertilizer levels on growth characters i.e. number of days from sowing to $50 \%$ tasseling, plant and ear height, stem diameter and ear leaf area was significant in the two growing seasons. It can be stated that all studied growth characters were significantly increased as a result of increasing nitrogen fertilizer levels from 90 up to $130 \mathrm{~kg} \mathrm{~N} / \mathrm{fed}$ and the differences between them were obvious in both seasons. Application the highest level of nitrogen fertilizer (130 kg N/fed) produced the highest values of growth parameters in both seasons. Fertilizing maize plants with $110 \mathrm{~kg} \mathrm{~N} / \mathrm{fed}$ came in the second rank after fertilizing with $130 \mathrm{~kg} \mathrm{~N} / \mathrm{fed}$ with respect to these characters. However, the lowest values of all growth traits were produced from fertilizing maize plants with $90 \mathrm{~kg} \mathrm{~N} / \mathrm{fed}$ in the first and second seasons of this investigation. The increase in growth traits associated with increasing nitrogen fertilization may be attributed to the role of nitrogen in enhancement meristematic activity and cell division which caused increase in internodes length, number of internodes and both of them. These results are in harmony with those recorded by Abd-Alla (2005), Sharifi and Taghizadeh (2009), Soliman and Gharib (2011) and Attia et al. (2012).

From obtained data in Tables 4 and 5, yield and its attributes; number of ears/plant, ear length $(\mathrm{cm})$, ear diameter $(\mathrm{cm})$, ear weight $(\mathrm{g})$, number of rows/ear, number of grains/row, ear grains weight $(\mathrm{g})$, shelling percentage (\%), 100-grain weight $(\mathrm{g})$ and grain yield (ardab/fed) as well as crude protein (\%) were significantly affected by nitrogen fertilizer levels in the two seasons. There were substantial differences in all studied characters among various studied nitrogen fertilizer levels in both seasons. Fertilizing maize plants with $130 \mathrm{~kg} \mathrm{~N} / \mathrm{fed}$ produced the highest values of yield and its attributes under study in both seasons. However, using $90 \mathrm{~kg} \mathrm{~N} / \mathrm{fed}$ was accompanied with the least values of yield and its components in the first and second seasons. It was worthy to mention that $110 \mathrm{~kg} \mathrm{~N} / \mathrm{fed}$ level arranged between aforementioned nitrogen fertilizer levels with respect their effect on of yield and its attributes in both seasons. The increase in grain yield and its attributes because of increasing nitrogen fertilizer levels up to $130 \mathrm{~kg} \mathrm{~N} / \mathrm{fed}$ can be easily ascribed to the role of nitrogen in activating growth of plants, consequently enhancement yield components (ear dimension, number and weight of grains/ear as well as 100-grain weight) and consequently increasing grain yield per unit area. These results are in compatible with those found by Abd-Alla (2005), Sharifi and Taghizadeh (2009), Arif et al. (2010) and Soliman and Gharib (2011). 
J. Plant Production, Mansoura Univ., Vol. 3 (12), December, 2012 


\section{Badawi, M. A. et al.}

4

3092 


\section{2- Effect of foliar spraying with growth promoters:}

The effect of foliar spraying with growth promoters (without spraying, spraying with water, Melagrow and Aminototal after 25, 35 and $25+35$ days from sowing) on maize growth characteristics i.e. number of days from sowing to $50 \%$ tasseling, plant and ear height, stem diameter and ear leaf area was significant in both seasons (Table 3). From obtained results, it could be observed that foliar spraying maize plants with Aminototal as a biostimulant substance after 25 and 35 DFS resulted in the highest values of studied growth characters in both growing seasons. It was followed by foliar spraying with Aminototal after 35 DFS, then foliar spraying with Aminototal after 25 DFS without significant differences between them in both seasons. It can be noticed that foliar spraying with Melagrow came after foliar spraying with Aminototal without fundamental differences between them and significantly exceeded foliar spraying with water at various times of application in both seasons. The lowest values of growth characters were resulted from control treatment (without foliar application) in the first and second seasons of this study. This increase in growth parameters by twice foliar application with Aminototal as a bio-stimulant substance which contained of 17 kinds of free amino acids in L-amino acids form as presented in Table 1 or Melagrow that contains phosphorus, potassium, boron and brassinolide may be due to the role of these growth promoters in regulating the nutrition of maize crop, preventing of some nutritive deficiencies and a nutrient cycle without impact processes, as well as, the role of brassinolides in improvement growth by increasing elongation of the internodes reflecting increases in plant height. These results were parallel with those reported by Mohamed (2006) and Ali et al. (2011).

There was significant effect on yield and its attributes (number of ears/plant, ear length, ear diameter, ear weight, number of rows/ear, number of grains/row, ear grains weight, shelling percentage, 100-grain weight and grain yield/fed as well as crude protein percentage) due to foliar application treatments (without spraying, spraying with water, Melagrow and Aminototal after 25,35 and $25+35$ days from sowing) in the two growing seasons (Tables 4 and 5).

From data it can be observed that, foliar spraying maize plants with Melagrow after $25+35$ days from sowing resulted in the highest values of number of ears/plant, ear length and diameter, ear weight, number of rows/ear, number of grains/row, ear grains weight, 100-grain weight and grain yield/fed and exceeded other spraying treatments in the first and second seasons of this study. It was followed by foliar spraying with Aminototal after $25+35$ DFS without significant differences between them in both seasons. In general, foliar spraying with Melagrow treatments exceeded Aminototal treatments at various times of application, but the differences among them were not significant in both seasons. Whereas, Melagrow or Aminototal treatments significantly exceeded water treatments at various times of application in both seasons. On the other hand, the control treatment (without foliar spraying) gave the lowest means of these characters in both seasons. The favorable effect of spraying maize plants twice after 25 and 35 days from sowing with Melagrow or Aminototal as natural growth promoters might have 


\section{Badawi, M. A. et al.}

been due to its effective role in improvement early maize growth, more dry matter accumulation and stimulated the building of metabolic products that translocated to grains. Moreover, the desirable effects of twice spraying with Melagrow or Aminototal in improvement in plant growth characters such as plant height, stem diameter and ear leaf area which reflected in turn increase in the different yield components such as number of ears/plant, ear length, ear diameter, ear grains weight and 100-grain weight. These findings are coincidence with those recorded by Mohamed (2006), Naderi et al. (2009), Radulov et al. (2010), El-Azab (2012) and Kasraie et al. (2012).

Concerning shelling percentage trait, the highest values were obtained from control treatment (without foliar application) in both seasons. It was followed by spraying with water after 25 DFS without significant differences in both seasons. However, the lowest values of this trait were produced by foliar spraying maize plants with $\mathrm{F}_{7}$ treatment (spraying with Melagrow after $25+35$ DFS) in both seasons.

While, foliar spraying maize plants with Aminototal twice after 25 and 35 DFS produced the highest means of crude protein content in maize grains in both seasons. It was followed by foliar spraying with Aminototal after 35 DFS in both growing seasons of this study. On the other side, the lowest values of crude protein content in maize grains were resulted from plants grown without foliar spraying in the two growing seasons. Such effect of foliar spraying with growth promoters on this trait may be reflected to its role in improvement growth and accumulation more assimilates that translocated to grains. These results stand in harmony with those obtained by Radulov et al. (2010) and Kasraie et al. (2012).

\section{3- Effect of interaction:}

Many significant interaction effects between both studied factors on number of days from sowing to $50 \%$ tasseling and plant height (in the second season only) and ear leaf area (in both seasons), number of ears/plant (in the second season), ear length (in the first season), shelling percentage, ear grains weight, 100-grain weight, grain yield/fed and crude protein percentage (in both seasons). The significant interaction between nitrogen fertilizer levels and foliar spraying with growth promoters on grain yield/fed was presented in Fig 1 and 2.

Maximum values of grain yield/fed were obtained from the highest level of mineral nitrogen fertilizer (130 kg N/fed) and foliar sprayed with Melagrow after $25+35$ DFS $\left(F_{7}\right)$, then foliar spraying with Aminototal after 25 + 35 DFS $\left(F_{10}\right)$, spraying with Melagrow after 25 DFS $\left(F_{5}\right)$ and spraying with Aminototal after 25 DFS $\left(F_{8}\right)$ during 2010 and 2011 seasons as graphically demonstrated in Figs 1 and 2, respectively. While, applied lowest nitrogen fertilizer level $(90 \mathrm{~kg} \mathrm{~N} / \mathrm{fed})$ without foliar spraying $\left(F_{1}\right)$ resulted in the lowest values of grain yield/fed in 2010 and 2011 seasons. These results stand in harmony with those founded by El-Azab (2012). 
J. Plant Production, Mansoura Univ., Vol. 3 (12), December, 2012 5

3095 


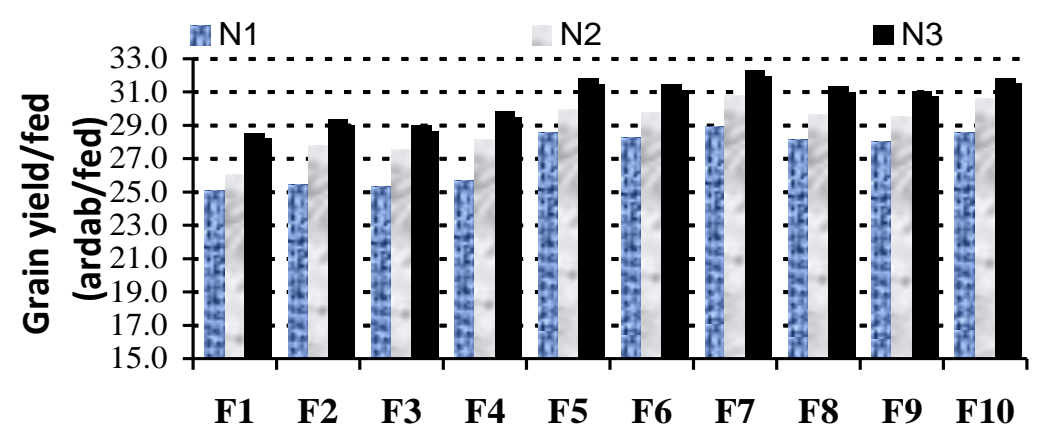

Fig. 1: Grain yield/fed of maize as affected by the interaction between nitrogen fertilizer levels and foliar spraying with growth promoters during 2010 season.

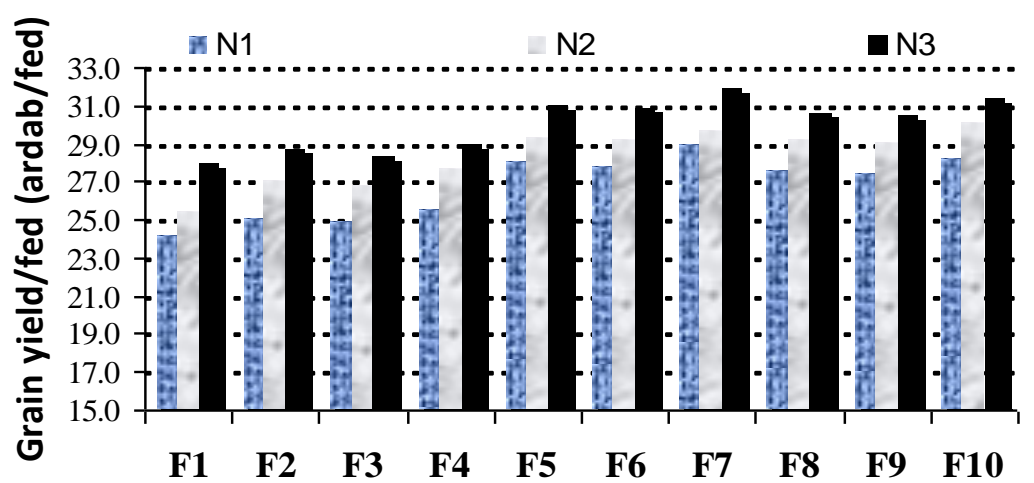

Fig. 2: Grain yield/fed of maize as affected by the interaction between nitrogen fertilizer levels and foliar spraying with growth promoters during 2011 season.

\section{REFERENCES}

A.O.A.C. (1990). Official Methods of Analysis. 15th Ed. Association of Official Analytical Chemists, Inc., Virginia, USA, pp: 770-771.

Abd El-Lattief, E.A. and A.A.O. Fakkar (2006). Growth, yield and yield components of maize (Zea mays L.) as influenced by nitrogen fertilization levels and mechanical weed control treatments. J. Agric. Sci. Mansoura Univ., 31(12): 7485-7496.

Abd-Alla, A.A. (2005). Maize yield potentiality in response to bio and mineral nitrogen fertilizers under drip irrigation regimes in the newly reclaimed soils. J. Agric. Sci. Mansoura Univ., 30 (10): 5765-5779.

Abdel-Hafez, S.A. ; H.A. Meshref ; Kh.H. El-Hamdi and Gh.Sh. El-Atawy (2008). Effect of irrigation, nitrogen and organic fertilization on soil water relationships of maize crop. J. Agric. Sci. Mansoura Univ., 33(7): 5409-5418. 
Ali, Z. ; S.M.A. Basra ; H. Munir ; A. Mahmood and S. Yousaf (2011). Mitigation of drought stress in maize by natural and synthetic growth promoters. J. Agric. Soc. Sci., 7: 56-62.

Arif, M. ; M.T Jan ; N.U. Khan ; H. Akbar ; S.A. Khan ; M.J. Khan ; A. Khan ; I. Munir ; M. Saeed and A. Iqbal (2010). Impact of plant populations and nitrogen levels on maize. Pakistan J. Bot., 42(6): 3907-3913.

Attia, A.N. ; S.A. El-Moursy ; E.M. Said ; S.E. Seadh and A.A.S. El-Azab (2012). Response of maize growth to organic and foliar fertilization under nitrogen fertilizer levels. J. Plant Production, Mansoura Univ., 3(6): 1063-1074.

Darwish, A.A. (2003). The yield and yield components of maize as influenced by nitrogen, zinc and boron fertilization. J. Agric. Sci. Mansoura Univ., 28 (2): 799-810.

El-Azab, A.A.S. (2012). Response of maize to organic and mineral fertilization under foliar application treatments. Ph. D. Thesis in Agron., Fac. of Agric. Mansoura Univ., Egypt.

El-Naggar, Nehal Z. A. ; M. A. Mohamed; S. A. Mowafy and I. M. Abd El-Hameed (2012). Effect of FYM and N fertilizer on yield and land use efficiency of maize - soybean intercropping. J. Plant Production, Mansoura Univ., 3 (5): $729-746$.

Gardner, F.P. ; R.B. Pearce and R.L. Michell (1985). Physiology of crop plant. lowa State Univ. Press Ames. Iowa. USA pp. 58-75 (C.F. Computer Search).

Gomez, K.N. and A.A. Gomez (1984). Statistical procedures for agricultural research. John Wiley and Sons, New York, 2 nd ed., $68 \mathrm{p}$.

Kasraie, P. ; M. Nasri and M. Khalatbari (2012). The effects of time spraying amino acid on water deficit stress on yield, yield component and some physiological characteristics of grain corn (TWC647). Annals of Biol. Res., 3 (9):4282-4286.

Ling, F. and M. Silberbush (2002). Response of maize to foliar vs. soil application of nitrogen-phosphorus-potassium fertilizers. J. of Plant Nutrition, 25 (11): 2333-2342.

Ma, B.L. ; K.D. Subedi and C. Costa (2005). Comparison of crop based indicators with soil nitrate test for corn nitrogen requirement. Agron. J., 97: 462-471.

Mohamed, A.M.A. (2006). Effect of some bio-chemical fertilization regimes on yield of maize. M. Sc. Thesis in Agron., Fac. of Agric. Zagazig Univ.

Naderi, M. R. ; A. Ardakani H. Naderi ; M. Madani and A. Boojar (2009). Response of maize to nutrients foliar application under water deficit stress conditions. American J. of Agric. and Biol. Sci., 4(3): 242-248.

Potarzycki, J. and W. Grzebisz (2009). Effect of zinc foliar application on grain yield of maize and its yielding components. Plant Soil Environ., 55 (12): 519-527.

Radulov I. ; F. Sala, E. Alexa, A. Berbecea and F. Crista (2010). Foliar fertilization influence on maize grain protein content and amino acid composition. Res. J. of Agric. Sci., 42 (3): 275-279. 


\section{Badawi, M. A. et al.}

Sawyer, J.E. and D. Barker (2000). Foliar fertilization of corn with monopotassium phosphate and urea. Final Res. Report, Dept. of Agron., lowa State Univ., pp: 1-13.

Seadh, S.E. and T.M. El-Zehery (2007). Integrated effect of mineral nitrogen fertilization and organic matter extract on maize productivity. Arab Conf. of Soil and Water Management for Sustainable Agricultural

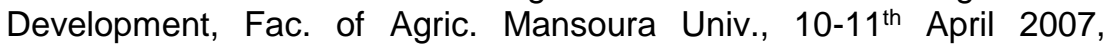
Mansoura, Egypt, pp. 435-443.

Seadh, S.E.; A.N.E. Attia; M. A. Badawi and S.M.S. El-Hety (2012). Response of seed yield and its components of safflower to sowing dates, nitrogen fertilizer levels and times of foliar application with Melagrow. J. Biol. Sci., 12(6): 342-348.

Sharifi, R.S. and R. Taghizadeh (2009). Response of maize (Zea mays L.) cultivars to different levels of nitrogen fertilizer. J. of Food, Agric. \& Environ., 7 (3\&4): 518 - 521.

Snedecor, G. W. and W. G. Cochran (1980). Statistical Methods, 7th Ed., Ames, IA: The lowa State University Press.

Soliman, I.E. and H.S. Gharib (2011). Response of weeds and maize (Zea mays L.) to some weed control treatments under different nitrogen fertilizer rates. Zagazig J. Agric. Res., 38 (2): 249-271.

Soliman, Salwa E. (2006) Effect of irrigation at different available soil moisture levels, $\mathrm{N}$ and $\mathrm{K}$ fertilization on maize yield and its attributes. J. Agric. Sci. Mansoura Univ., 31(12): 7525-7540.

Wopereis, M.C.S. ; A. Tamelokpo ; K. Ezui ; D. Gnakpenou ; B. Fofana and $\mathrm{H}$. Breman (2006). Mineral fertilizer management of maize on farmer differing in organic inputs in the West African savanna. Field Crops Res., 96: 355-362. 


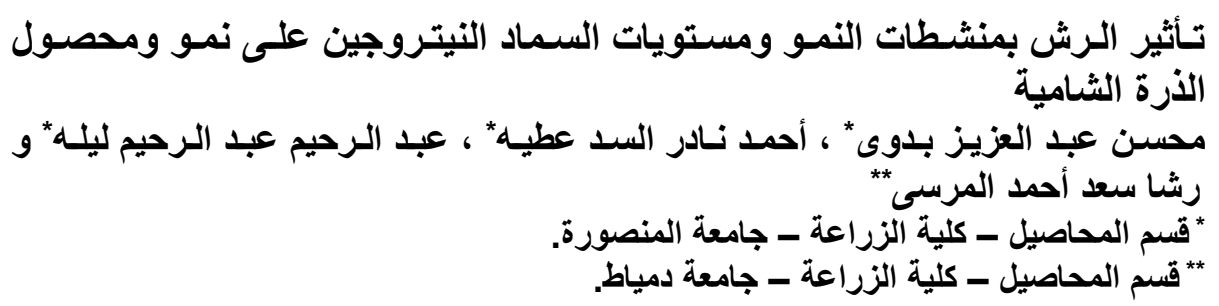

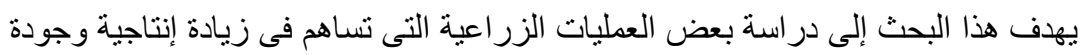

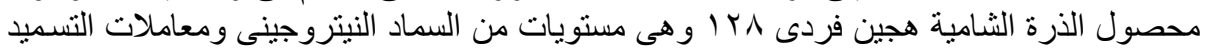

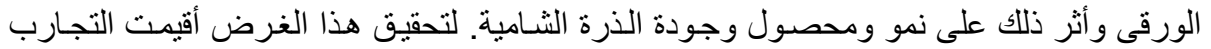

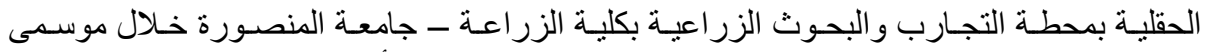

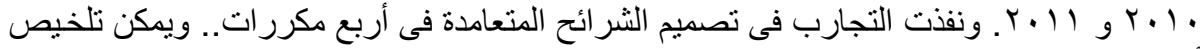

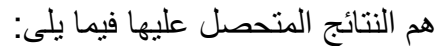

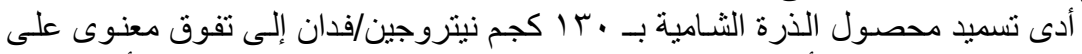

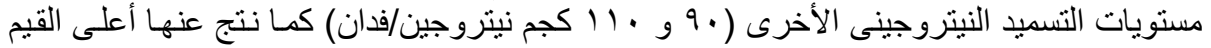

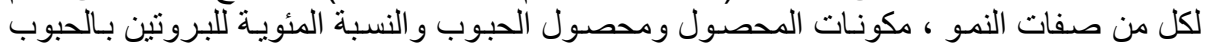

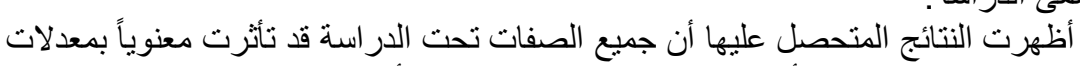
خلال موسمى الدر اسة.

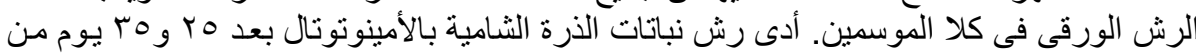

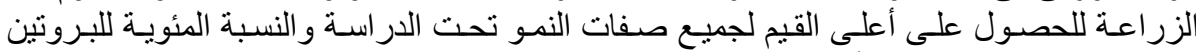

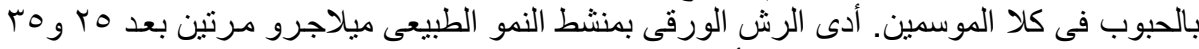

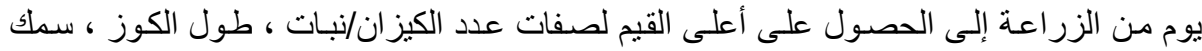

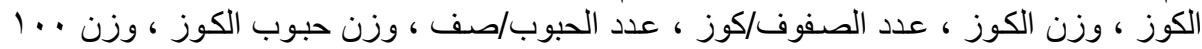

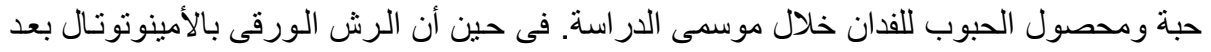

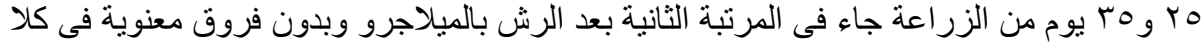

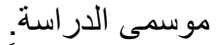

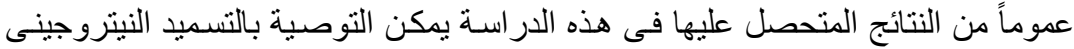

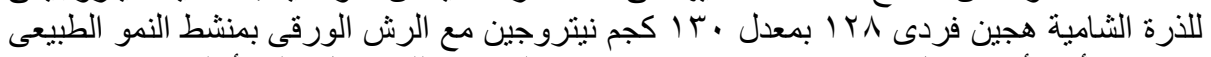

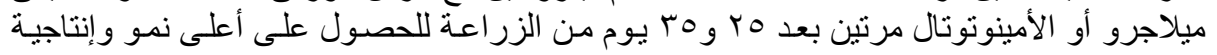

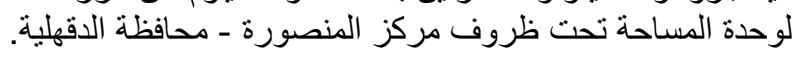

كلية الزراعة - جامعة المنصورة قام بتحكيم البحث كلية الزراعة ـ جامعة القاهره 
Badawi, M. A. et al. 
Table 3: Number of days from sowing to $50 \%$ tasseling, plant and ear height, stem diameter and ear leaf area of maize as affected by nitrogen fertilizer levels and foliar spraying with growth promoters as well as their interaction during 2010 and 2011 seasons.

\begin{tabular}{|c|c|c|c|c|c|c|c|c|c|c|}
\hline \multirow{2}{*}{ Characters } & \multicolumn{2}{|c|}{$\begin{array}{c}\text { No. of days } \\
\text { from sowing to } \\
50 \% \text { tasseling }\end{array}$} & \multicolumn{2}{|c|}{$\begin{array}{l}\text { Plant height } \\
\text { (cm) }\end{array}$} & \multicolumn{2}{|c|}{$\begin{array}{l}\text { Ear height } \\
\text { (cm) }\end{array}$} & \multicolumn{2}{|c|}{ Stem diameter $(\mathbf{c m})$} & \multicolumn{2}{|c|}{$\begin{array}{l}\text { Ear leaf area } \\
\qquad\left(\mathrm{cm}^{2}\right)\end{array}$} \\
\hline & 2010 & 2011 & 2010 & 2011 & 2010 & 2011 & 2010 & 2011 & 2010 & 2011 \\
\hline \multicolumn{11}{|c|}{ A- Nitrogen fertilizer levels: } \\
\hline $\mathrm{N}_{1}-90 \mathrm{~kg} \mathrm{~N} / \mathrm{fed}$ & 58.02 & 57.86 & 290.5 & 285.22 & 144.7 & 143.0 & 2.20 & 2.13 & 639.7 & 633.6 \\
\hline $\mathrm{N}_{2}-110 \mathrm{~kg} \mathrm{~N} / \mathrm{fed}$ & 58.23 & 58.10 & 300.1 & 294.77 & 151.7 & 149.4 & 2.29 & 2.24 & 673.2 & 664.4 \\
\hline $\mathrm{N}_{3}-130 \mathrm{~kg} \mathrm{~N} / \mathrm{fed}$ & 58.60 & 59.25 & 309.3 & 304.02 & 167.0 & 164.7 & 2.37 & 2.30 & 706.9 & 686.1 \\
\hline F. test & * & * & ${ }^{*}$ & * & * & * & * & * & * & * \\
\hline LSD at $5 \%$ & 0.30 & 0.31 & 2.3 & 1.3 & 1.8 & 2.1 & 0.07 & 0.02 & 2.5 & 2.4 \\
\hline \multicolumn{11}{|c|}{ B-Foliar spraying with growth promoter: } \\
\hline$F_{1}-$ Without (control) & 57.98 & 57.85 & 286.0 & 283.9 & 143.8 & 142.0 & 2.13 & 2.06 & 629.0 & 624.0 \\
\hline $\mathrm{F}_{2}-$ Spraying with water after $25 \mathrm{DFS}$ & 58.12 & 57.97 & 291.3 & 286.5 & 146.6 & 145.1 & 2.14 & 2.09 & 636.4 & 628.5 \\
\hline $\mathrm{F}_{3}-$ Spraying with water after $35 \mathrm{DFS}$ & 58.21 & 58.09 & 294.0 & 287.5 & 148.6 & 146.8 & 2.20 & 2.15 & 640.8 & 631.7 \\
\hline $\mathrm{F}_{4^{-}}$Spraying with water after $25+35 \mathrm{DFS}$ & 58.22 & 58.34 & 294.6 & 288.6 & 149.8 & 148.2 & 2.18 & 2.15 & 648.9 & 639.3 \\
\hline $\mathrm{F}_{5}$-Spraying with Melagrow after 25 DFS & 58.20 & 58.37 & 303.5 & 295.6 & 155.3 & 152.8 & 2.29 & 2.22 & 682.7 & 674.8 \\
\hline $\mathrm{F}_{6}$-Spraying with Melagrow after $35 \mathrm{DFS}$ & 58.25 & 58.41 & 304.1 & 297.0 & 157.0 & 153.4 & 2.30 & 2.20 & 690.0 & 677.8 \\
\hline $\begin{array}{c}F_{7-} \text { Spraying with Melagrow after } 25+35 \\
\text { DFS }\end{array}$ & 58.27 & 58.49 & 305.1 & 300.0 & 158.0 & 153.9 & 2.40 & 2.32 & 699.5 & 685.6 \\
\hline$F_{8^{-}}$Spraying with Aminototal after 25 DFS & 58.40 & 58.61 & 305.6 & 301.0 & 161.3 & 158.7 & 2.35 & 2.30 & 694.8 & 676.6 \\
\hline$F_{9^{-}}$Spraying with Aminototal after 35 DFS & 58.46 & 58.90 & 306.0 & 302.3 & 161.9 & 161.2 & 2.41 & 2.35 & 704.0 & 686.5 \\
\hline $\begin{array}{l}F_{10}-\text { Spraying with Aminototal after } 25+35 \\
\text { DFS }\end{array}$ & 58.70 & 59.00 & 309.1 & 304.0 & 162.5 & 161.5 & 2.46 & 2.38 & 706.8 & 688.9 \\
\hline F. test & * & * & * & * & * & * & * & * & * & * \\
\hline LSD at $5 \%$ & 0.40 & 0.56 & 3.7 & 4.0 & 2.8 & 2.2 & 0.11 & 0.13 & 9.7 & 6.3 \\
\hline C-Interaction: $\mathrm{A} \times \mathrm{B}$ & NS & & NS & & NS & NS & NS & NS & & \\
\hline
\end{tabular}


Table 4: Number of ears/plant, ear length, diameter and weight, number of rows/ear and number of grains/row of maize as affected by nitrogen fertilizer levels and foliar spraying with growth promoters as well as their interaction during 2010 and 2011 seasons.

\begin{tabular}{|c|c|c|c|c|c|c|c|c|c|c|c|c|}
\hline \multirow{2}{*}{\begin{tabular}{|l|l|} 
& Characters \\
Treatments
\end{tabular}} & \multicolumn{2}{|c|}{$\begin{array}{l}\text { Number of } \\
\text { ears/plant }\end{array}$} & \multicolumn{2}{|c|}{$\begin{array}{l}\text { Ear length } \\
\text { (cm) }\end{array}$} & \multicolumn{2}{|c|}{$\begin{array}{l}\text { Ear diameter } \\
\text { (cm) }\end{array}$} & \multicolumn{2}{|c|}{$\begin{array}{l}\text { Ear weight } \\
(\mathrm{g})\end{array}$} & \multicolumn{2}{|c|}{$\begin{array}{l}\text { Number of } \\
\text { rows/ear }\end{array}$} & \multicolumn{2}{|c|}{$\begin{array}{l}\text { Number of } \\
\text { grains/row }\end{array}$} \\
\hline & 2010 & 2011 & 201 & & 2011 & 2010 & 2011 & 2010 & & & 2010 & 2011 \\
\hline \multicolumn{13}{|c|}{ A- Nitrogen fertilizer levels: } \\
\hline$N_{1}-90 \mathrm{~kg} \mathrm{~N} / \mathrm{fed}$ & 1.25 & 1.18 & 21.73 & 21.59 & $\begin{array}{ll}4.78 \\
\end{array}$ & 4.58 & 236.9 & 226.5 & 14.08 & 13.88 & 40.07 & 39.66 \\
\hline $\mathrm{N}_{2}-110 \mathrm{~kg} \mathrm{~N} / \mathrm{fed}$ & 1.33 & 1.31 & 23.10 & 22.65 & 4.87 & 4.63 & 242.7 & 239.6 & 14.45 & 14.23 & 42.68 & 42.50 \\
\hline $\mathrm{N}_{3}-130 \mathrm{~kg} \mathrm{~N} / \mathrm{fed}$ & 1.38 & 1.37 & 25.79 & 25.28 & 5.24 & 5.05 & 251.2 & 247.0 & 15.57 & 15.33 & 46.34 & 45.96 \\
\hline F. test & * & * & ${ }^{*}$ & * & * & * & ${ }^{*}$ & ${ }^{*}$ & * & * & ${ }^{*}$ & * \\
\hline LSD at $5 \%$ & 0.02 & 0.01 & \begin{tabular}{|l|}
0.23 \\
\end{tabular} & 0.27 & 0.12 & 0.12 & 4.6 & 2.4 & 0.11 & 0.14 & 0.68 & 0.25 \\
\hline \multicolumn{13}{|c|}{ B-Foliar spraying with growth promoter: } \\
\hline$F_{1}$ - Without (control) & 1.22 & 1.20 & \begin{tabular}{|c|}
21.65 \\
\end{tabular} & 21.37 & 4.65 & 4.44 & 224.0 & 219.6 & 14.18 & 13.98 & 40.55 & 40.29 \\
\hline$F_{2^{-}}$Spraying with water after $25 \mathrm{DFS}$ & 1.23 & 1.20 & 22.48 & 22.14 & 4.91 & 4.77 & 234.4 & 227.1 & 14.39 & 14.18 & 41.32 & 41.20 \\
\hline$F_{3}-$ Spraying with water after 35 DFS & 1.24 & 1.22 & 22.07 & 21.91 & 4.59 & 4.42 & 231.0 & 225.0 & 14.24 & 14.04 & 40.66 & 40.54 \\
\hline $\begin{array}{l}F_{4-} \text { Spraying with water after } 25+35 \\
\text { DFS }\end{array}$ & 1.26 & 1.25 & 22.91 & 22.63 & 4.75 & 4.54 & 239.9 & 230.5 & 14.58 & 14.32 & 42.15 & 41.63 \\
\hline $\begin{array}{l}F_{5} \text {-Spraying with Melagrow after } 25 \\
\text { DFS }\end{array}$ & 1.38 & 1.33 & 24.32 & 23.92 & 5.17 & 4.95 & 252.0 & 248.2 & 14.97 & 14.74 & 44.52 & 44.05 \\
\hline $\begin{array}{l}F_{6}-\text { Spraying with Melagrow after } 35 \\
\text { DFS }\end{array}$ & 1.39 & 1.34 & 24.10 & 23.79 & 4.99 & 4.80 & 246.1 & 241.9 & 14.76 & 14.58 & 44.00 & 43.54 \\
\hline \begin{tabular}{|l|}
$F_{7-}$ Spraying with Melagrow after $25+$ \\
35 DFS
\end{tabular} & 1.42 & 1.37 & 25.03 & 24.38 & 5.46 & 5.05 & 259.7 & 252.0 & 15.20 & 14.95 & 45.27 & 44.85 \\
\hline \begin{tabular}{|l|} 
F $^{-}$Spraying with Aminototal after 25 \\
DFS
\end{tabular} & 1.34 & 1.31 & 24.10 & 23.72 & 4.98 & 4.85 & 249.0 & 242.6 & 14.81 & 14.61 & 43.84 & 43.57 \\
\hline $\begin{array}{c}F_{9-}-\text { Spraying with Aminototal after } 35 \\
\text { DFS }\end{array}$ & 1.33 & 1.31 & 23.90 & 23.65 & 4.80 & 4.71 & 244.8 & 240.5 & 14.71 & 14.50 & 43.36 & 43.27 \\
\hline $\begin{array}{l}\mathrm{F}_{10}-\text { Spraying with Aminototal after } 25 \\
+35 \text { DFS }\end{array}$ & 1.39 & 1.34 & 24.81 & 24.24 & 5.32 & 5.01 & 254.8 & 249.3 & 15.15 & 14.92 & 44.60 & 44.12 \\
\hline F. test & * & * & ${ }^{*}$ & ${ }^{*}$ & ${ }^{*}$ & * & ${ }^{*}$ & ${ }^{*}$ & ${ }^{*}$ & * & ${ }^{*}$ & ${ }^{*}$ \\
\hline LSD at $5 \%$ & 0.03 & 0.03 & 0.65 & 0.46 & 0.23 & 0.27 & 7.7 & 6.2 & 0.24 & 0.30 & 0.99 & 0.85 \\
\hline C-Interaction: A X B & NS & & & NS & NS & NS & NS & NS & NS & NS & NS & NS \\
\hline
\end{tabular}


J. Plant Production, Mansoura Univ., Vol. 3 (12), December, 2012

Table 5: Ear grains weight, shelling percentage, 100-grain weight, grain yield/fed and crude protein content in maize grains as affected by nitrogen fertilizer levels and foliar spraying with growth promoters as well as their interaction during 2010 and 2011 seasons.

\begin{tabular}{|c|c|c|c|c|c|c|c|c|c|c|}
\hline \multirow{2}{*}{\begin{tabular}{|l} 
Characters \\
Treatments
\end{tabular}} & \multicolumn{2}{|c|}{ Ear grains weight $\mathbf{( g )}$} & \multicolumn{2}{|c|}{$\begin{array}{l}\text { Shelling } \\
(\%)\end{array}$} & \multicolumn{2}{|c|}{ 100-grain weight $(g)$} & \multicolumn{2}{|c|}{$\begin{array}{l}\text { Grain yield } \\
\text { (ardab/fed) }\end{array}$} & \multicolumn{2}{|c|}{$\begin{array}{l}\text { Protein content } \\
\text { (\%) }\end{array}$} \\
\hline & 2010 & 2011 & 2010 & 2011 & 2010 & 2011 & 2010 & 2011 & 2010 & 2011 \\
\hline \multicolumn{11}{|c|}{ A- Nitrogen fertilizer levels: } \\
\hline$N_{1}-90 \mathrm{~kg} \mathrm{~N} / \mathrm{fed}$ & 176.4 & 174.5 & 74.64 & 77.20 & 47.05 & 46.86 & 27.22 & 26.75 & 7.43 & 7.48 \\
\hline $\mathrm{N}_{2^{-}}-110 \mathrm{~kg} \mathrm{~N} / \mathrm{fed}$ & 184.4 & 182.9 & 76.11 & 76.42 & 47.77 & 47.43 & 28.99 & 28.36 & 7.53 & 7.58 \\
\hline $\mathrm{N}_{3}-130 \mathrm{~kg} \mathrm{~N} / \mathrm{fed}$ & 203.8 & 200.8 & 81.13 & 81.31 & 49.49 & 49.26 & 30.66 & 29.99 & 7.67 & 7.71 \\
\hline F. test & * & ${ }^{*}$ & ${ }^{*}$ & ${ }^{*}$ & * & ${ }^{*}$ & ${ }^{*}$ & ${ }^{*}$ & * & * \\
\hline LSD at $5 \%$ & 1.86 & 1.15 & 1.65 & 0.86 & 0.13 & 0.37 & 0.35 & 0.20 & 0.02 & 0.03 \\
\hline \multicolumn{11}{|c|}{ B-Foliar spraying with growth promoter: } \\
\hline$F_{1}-$ Without (control) & 178.6 & 177.2 & 79.79 & 80.79 & 47.02 & 46.62 & 26.58 & 25.83 & 7.18 & 7.23 \\
\hline $\begin{array}{l}\mathrm{F}_{2^{-}} \\
\begin{array}{l}\text { Spraying with water after } 25 \\
\text { DFS }\end{array}\end{array}$ & 181.6 & 180.1 & 77.98 & 79.33 & 47.38 & 47.15 & 27.53 & 26.95 & 7.26 & 7.29 \\
\hline $\begin{array}{c}F_{3}-\begin{array}{l}\text { Spraying with water after } 35 \\
\text { DFS }\end{array} \\
\end{array}$ & 180.0 & 178.4 & 77.52 & 79.32 & 47.19 & 46.98 & 27.31 & 26.70 & 7.24 & 7.27 \\
\hline $\begin{array}{l}\mathrm{F}_{4^{-}} \text {Spraying with water after } 25+ \\
35 \mathrm{DFS}\end{array}$ & 183.1 & 181.7 & 76.34 & 78.84 & 47.69 & 47.55 & 27.89 & 27.38 & 7.31 & 7.35 \\
\hline $\begin{array}{l}F_{5} \text {-Spraying with Melagrow after } 25 \\
\text { DFS }\end{array}$ & 193.5 & 190.8 & 76.79 & 77.79 & 48.56 & 48.25 & 30.10 & 29.45 & 7.62 & 7.67 \\
\hline $\begin{array}{l}\mathrm{F}_{6} \text {-Spraying with Melagrow after } 35 \\
\text { DFS }\end{array}$ & 191.1 & 188.6 & 77.61 & 77.91 & 48.36 & 48.21 & 29.83 & 29.28 & 7.56 & 7.66 \\
\hline $\begin{array}{l}F_{7^{-}} \text {Spraying with Melagrow after } \\
25+35 \text { DFS }\end{array}$ & 198.2 & 196.2 & 76.25 & 76.51 & 49.30 & 48.89 & 30.69 & 30.18 & 7.70 & 7.72 \\
\hline $\begin{array}{l}\mathrm{F}_{8^{-}} \text {Spraying with Aminototal after } \\
25 \mathrm{DFS}\end{array}$ & 190.1 & 187.5 & 76.34 & 77.26 & 48.27 & 48.15 & 29.73 & 29.15 & 7.76 & 7.77 \\
\hline $\begin{array}{l}\text { F9- Spraying with Aminototal after }^{35 \mathrm{DFS}} \\
\end{array}$ & 189.4 & 185.7 & 77.34 & 77.21 & 48.15 & 47.95 & 29.55 & 28.95 & 7.84 & 7.90 \\
\hline $\begin{array}{l}F_{10^{-}} \text {Spraying with Aminototal after } \\
25+35 \text { DFS }\end{array}$ & 196.2 & 194.2 & 76.96 & 78.17 & 49.12 & 48.73 & 30.37 & 29.82 & 7.99 & 8.03 \\
\hline F. test & ${ }^{*}$ & ${ }^{*}$ & ${ }^{*}$ & ${ }^{*}$ & ${ }^{*}$ & ${ }^{*}$ & ${ }^{*}$ & ${ }^{*}$ & ${ }^{*}$ & ${ }^{*}$ \\
\hline LSD at $5 \%$ & 2.83 & 2.00 & 2.54 & 2.04 & 0.63 & 0.39 & 0.46 & 0.51 & 0.07 & 0.04 \\
\hline C- Interaction: A X B & & & & & & & & & & \\
\hline
\end{tabular}

